\title{
Submandibular gland excision
}

\section{Ressecção da glândula submandibular}

\author{
Alexandre Sanfurgo de Carvalho ${ }^{1}$; Rogério Aparecido Dedivitis, TCBC-SP²; Mario Augusto Ferrari de Castro 3 ; Carlos Eduardo \\ MOLINARI NARDI ${ }^{4}$
}

A B S T R A C T

\begin{abstract}
Objective: to analyze the value of fine needle aspiration and the rates of postoperative complications in patients undergoing resection of the submandibular gland. Methods: we analyzed the records of patients treated with resection of the gland from January 1995 to December 2008. The data collected included age, gender, findings on clinical history, surgical procedure, results of fine needle aspiration (FNA), pathological diagnosis and complications.Results: 117 patients were studied, aged 12-89 years (mean 48), 70 women and 47 men. Thirty-nine patients (33.3\%) were affected by inflammatory diseases (28 patients with lithiasis), 70 had benign tumors, and malignant tumors, eight. Regarding FNA, the sensitivity and specificity were $85.7 \%$ and $100 \%$, respectively. Nine patients $(7.7 \%)$ had temporary paralysis of the marginal mandibular nerve and one had permanent paralysis. Conclusion: resection of the submandibular gland is a safe procedure, with low complication rates.
\end{abstract}

Key words: Submandibular gland. Submandibular gland diseases. Submandibular gland neoplasms. Sialadenitis. Salivary gland calculi.

\section{INTRODUCTION}

T he submandibular gland is affected by various types of diseases, be them degenerative, inflammatory or neoplastic ${ }^{1}$. The most common clinical presentation is the edematous increase of the gland. The differentiation between a neoplastic disorder or not can be difficult ${ }^{2}$. Submandibular gland tumors account for about $3 \%$ of all tumors of the head and neck. Approximately $10 \%$ of tumors of the salivary glands are located in the submandibular gland, with a high rate of malignancy, though sialolithiasis and inflammatory diseases are also found ${ }^{3}$. The most found benign tumor is the pleomorphic adenoma. Total resection of the affected gland is the standard treatment proposed for all tumors.

The surgical transcervical lateral access is considered standard for approach the submandibular gland ${ }^{4}$. Although other open and endoscopic approaches have been proposed $^{5}$, the lateral transcervical remains the only one used in our Department.

The report of operative complications in the submandibular gland excision for benign lesions ranges from 0 to $14 \%$ for hematoma and infection. However, the need of reoperation is rarely reported ${ }^{3,6,7}$. Subjective complaints are also reported by some patients. Permanent damage to the marginal mandibular branch of the facial nerve accounts for 0 to $8 \%$, the lingual nerve, 0 to $12 \%$, and the hypoglossal, 0 to $1.4 \%^{1,6-8}$.

The objective of this study is to analyze the value of fine needle aspiration and the rates of postoperative complications in patients undergoing resection of the submandibular gland.

\section{METHODS}

We reviewed the records of unselected cases of patients treated with resection of the submandibular gland in the Head and Neck Surgery Service at the Hospital Ana Costa and at the Irmandade da Santa Casa da Misericórdia de Santos, São Paulo - SP, Brazil, from January 1995 to December 2008. The data analyzed were age, gender, findings on clinical history, results of FNA, indication for surgery, surgical procedure, histological diagnosis and complications. Clinical examination was performed with bimanual palpation to differentiate between glandular tissue and lymph node.

The evaluated postoperative complications were hematoma, wound infection, salivary fistula and paralysis of the hypoglossal, marginal mandibular and lingual nerves. The physiological function of each involved nerve was clinically assessed before and after surgery by observing

1. General Surgery Service, Hospital Ana Costa, Santos, São Paulo State, Brazil; 2. Department of Head and Neck Surgery, Faculty of Medicine, Hospital das Clínicas, Universidade de São Paulo, São Paulo State, Brazil; 3. Faculty of Medical Sciences, Lusiadas UNILUS Foundation, Santos, São Paulo State, Brazil; 4. Head and Neck Surgery Service, Hospital Ana Costa, Santos, São Paulo State, Brazil. 
the movements of the facial muscles and the appearance, movement and tactile sensation of the tongue. We performed the postoperative evaluation at the time of skin suture removal, and if there were nerve changes, we carried out periodic reviews until complete resolution of paresthesia.

Ultrasonography was performed routinely as a complementary imaging study to clinical findings. The fine needle aspiration with frozen specimen was performed in patients with nodular disease of the submandibular gland to clarify the benign or malignant nature of the lesion, not being indicated for patients with stone disease and other inflammatory diseases. After resection, the submandibular gland was sent for pathological examination.

All patients were followed for a minimum of six months, with 12 months of mean follow-up for patients with benign diseases and 48 months in the case of malignancy. Patients with calculi palpable on the floor of the mouth, submitted to intraoral resection through the duct of Wharton, were not included.

\section{RESULTS}

We studied 117 patients aged 12-89 years (mean 48), 70 of them women and 47 men (1.49:1); 39 (33.3\%) were affected by lithiasic inflammatory disease and 78 (66.6\%) underwent resection of the gland due to benign or malignant neoplastic disease. The initial presentation of patients with neoplastic disease was the finding of an asymptomatic palpable mass, 70 patients having pleomorphic adenoma and eight, carcinoma.

Among the patients suffering from inflammatory diseases, 22 presented with a palpable asymptomatic mass, 17 complained of localized edema and pain. On physical examination, the glands had hardened. We found evidence of acute infectious processess in five cases. Ultrasonography revealed the presence of sialolithiasis in 28 patients. These findings were confirmed with the examination of the resected glands (Table 1); $59.8 \%$ of lesions analyzed were pleomorphic adenoma and 33.3\%, sialoadenitis, with or without sialolithiasis. There was no bilateral glandular inflammation.

With respect to fine needle aspiration, the sensitivity and specificity for detecting malignancy was $87.5 \%$ and $100 \%$, respectively (Table 2 ).

Patients with pleomorphic adenoma showed no local recurrence or disease during follow-up. One patient with carcinoma ex-adenoma underwent glandular resection and adjuvant radiotherapy with unilateral radical dissection, but died after four months of treatment due to pulmonary metastasis. The seven patients with carcinoma who underwent resection of the gland and unilateral supraomohyoid emptying were not referred to radiotherapy; none had recurrence. Patients with inflammatory diseases who underwent excision of the gland were asymptomatic in the postoperative period.
There was one case of hematoma, conducted with conservative therapy. Nine patients (7.7\%) had neuropraxis of the marginal mandibular branch of the facial nerve and had good resolution in two to six months. The patient with carcinoma ex-adenoma had permanent paralysis (Table 3 ).

\section{DISCUSSÃO}

Each submandibular gland weighs around 10 to 15 grams and is divided anatomically into superficial and deep lobe by the posterior end of the mylohyoid muscle. The artery and facial vein, as well as the hypoglossal, lingual and marginal mandibular branch of the facial nerve, have close relationship with the gland. Damage to these structures can result in increased morbidity after operation. The submandibular gland secretes on average $71 \%$ of the daily produced saliva, consisting of serous and mucous component. Its secretion is crucial for lubricating and swallowing of the bolus, in addition to enzyme digestion, which starts in the upper digestive tract ${ }^{1}$.

The submandibular gland is usually not noticed. When increased in size, however, it is bimanually palpable ${ }^{1}$. The first diagnostic evidence is a mass in the submandibular region. Inflammatory diseases often present with pain, fever, purulent secretion through the duct of Wharton and fast growth ${ }^{9}$. Usually the clinical differentiation between an inflammatory or neoplastic disease is not difficult. Although

Table 1 - Incidence of diseases of the submandibular gland $(\mathrm{N}=117)$.

\begin{tabular}{lrr}
\hline Disease & N & $\%$ \\
\hline Non-neoplastic & 39 & $33.3 \%$ \\
$\quad$ Chronic Inflammation & 11 & $9.4 \%$ \\
$\quad$ Lithiasis & 28 & $23.9 \%$ \\
Benign Neoplasias & 70 & $59.8 \%$ \\
$\quad$ Pleomorphic Adenoma & 70 & $59.8 \%$ \\
Malignant Neoplasias & 8 & $6.8 \%$ \\
Mucoepidermoid Carcinoma & 3 & $2.5 \%$ \\
Adenoid Cystic Carcinoma & 3 & $2.5 \%$ \\
Carcinoma of acinar cells & 1 & $0.85 \%$ \\
Carcinoma ex-adenoma & 1 & $0.85 \%$ \\
\hline
\end{tabular}

Table 2 - Results of fine needle aspiration (FNA) of tumors of the submandibular gland $(\mathrm{N}=78)$.

\begin{tabular}{lcc} 
& Negative & Positive \\
\hline & Histopathology & Histopathology \\
\hline Negative FNA & 70 & 1 \\
Positive FNA & 0 & 7 \\
\hline
\end{tabular}


Table 3 - Perioperative neural complications of submandibular gland resection.

\begin{tabular}{lcccc}
\hline Nerve & Damage & Inflammatory disease & Benign tumor & Malignant tumor \\
\hline Hypoglossal & Paresis / paralysis & 0 & 0 & 0 \\
Lingual & Paresis / paralysis & 0 & 0 & 0 \\
Marginal Mandibular & Transient paresis & 6 & 1 & 3 \\
& Permanent paralysis & 0 & 0 & 1 \\
\hline
\end{tabular}

tumors or inflammatory processes produce increase of the gland with firm to hardened consistency, tumors tend to be more irregular, with lobed contours. In case of difficulty in the clinical diagnosis of the lesion, diagnostic resection of the gland should be performed'.

The distribution of inflammatory and neoplastic lesions of the submandibular glands is different from the one of the parotid gland, in which the incidence of cancer is significant ${ }^{4}$. There is reported prevalence of neoplastic disease $(66.6 \%)$ in contrast to other findings, with up to $76 \%$ of inflammatory affections ${ }^{2}$. The most common disease in this study was chronic inflammation in 109 of 185 patients, the incidence of reported tumor involvement being present in $14 \%$ of cases, with prevalence of malignant tumors ${ }^{2}$. In our sample, containing 117 patients, 39 (33.3\%) were affected by lithiasic inflammatory disease and 78 (66.6\%) by neoplastic disease, of which 70 had benign tumors and eight, malignancy.

Chronic inflammation and lithiasis have a higher incidence in diseases of the submandibular gland. Diagnosis can be made by plain radiography, ultrasound and sialography. Computed tomography and biopsy by fine needle aspiration should be reserved for cases of suspected neoplasia ${ }^{10}$.

Defined as acute, subacute or chronic inflammation, sialodenitis results from of a variety of obstructive (calcullus duct obstruction) or not obstructive causes (systemic diseases, trauma and specific infective agents). In any case, the causal factor is unknown. Sialolithiasis is found in $24 \%$ of patients with sialodenitis. Compared with other salivary glands, the submandibular is more prone to calculus formation. Ninety percent of the salivary calculi have submandibular origin. Although still speculative, causal factors have been attributed to other reasons, whether physicochemical (high content of mucus, alkaline $\mathrm{pH}$, high concentration of organic materials, calcium and phosphorus present in the submandibular saliva) or anatomical (duct with long and irregular course, small ductal drainage orifice and position) ${ }^{1}$. In the group studied, calculi were found in 28 of 39 patients with sialoadenitis $(71.9 \%)$, probably due to preferred conservative therapy in patients with mildly symptomatic inflammatory diseases.

Most patients with neoplastic disease of the submandibular gland showed painless gland enlargement. The pain experienced by a small portion of patients with neoplastic disease may be due to rapid stretching of the capsule $^{1}$. As in other studies ${ }^{11,12}$, fine needle aspiration remains a valuable tool for the preoperative evaluation of patients with suspected malignancy. In this series, fine needle aspiration was performed in 78 patients with suspected cancer, with a sensitivity of $85.7 \%$ and specificity of $100 \%$. Tumors have been reported involving the gland, with a high rate of adenoid cystic carcinoma ${ }^{13}$

The submandibular gland is closely related to the marginal mandibular branch of the facial nerve, lingual and hypoglossal nerves. These nerves do not pass through the gland, such as with the parotid. This means that small iatrogenic paralysis can occur due to dissection. In this series, the genial branch was affected in $8.5 \%$ of cases, only $0.85 \%$ permanently (one case of advanced carcinoma exadenoma). Hypoglossal or lingual nerve palsy has been observed by other authors ${ }^{10}$.

In conclusion, the major diseases of the submandibular gland that justify surgical treatment are pleomorphic adenoma and sialodenitis with sialolithiasis. The excision of the submandibular glands has low morbidity, with few complications.

\section{RE S U M O}

Objetivo: analisar o valor da punção aspirativa por agulha fina e os índices de complicações pós-operatórias em pacientes submetidos à ressecção da glândula submandibular. Métodos: foram analisados os prontuários de pacientes tratados com a ressecção da glândula, de janeiro de 1995 a dezembro de 2008. Os dados coletados foram: idade, sexo, achados na história clínica, procedimento cirúrgico, resultados da punção por aspiração com agulha fina (PAAF), diagnóstico anatomopatológico e complicações. Resultados: foram estudados 117 pacientes, com idade variando de 12 a 89 anos (média, 48 anos), sendo 70 mulheres e 47 homens. Trinta e nove pacientes (33,3\%) foram acometidos por doenças inflamatórias (28 pacientes com litíase), 70 tiveram tumores benignos e oito tumores malignos. A respeito da PAAF, a sensibilidade e especificidade foram de $85,7 \%$ e $100 \%$, respectivamente. Nove pacientes $(7,7 \%)$ tiveram paralisia temporária do nervo mandibular marginal e um apresentou paralisia definitiva. Conclusão: a ressecção da glândula submandibular é um procedimento seguro, com baixa taxa de complicações.

Descritores: Glândula Submandibular. Doenças da Glândula Submandibular. Neoplasias da Glândula Submandibular. Sialadenite. Cálculos das glândulas salivares. 


\section{REFERENCES}

1. Goh YH, Sethi DS. Submandibular gland excision: a five-year review. J Laryngol Otol. 1998;112(3):269-73.

2. Gallina E, Gallo O, Boccuzzi S, Paradiso P. Analysis of 185 submandibular gland excisions. ActaOtorhinolaryngol Belg. 1990;44(1):7-10

3. Preuss SF, Klussmann JP, Wittekindt C, Drebber U, Beutner D, Guntinas-Lichius O. Submandibular gland excision: 15 years of experience. J Oral Maxillofac Surg. 2007;65(5):953-7.

4. Springborg LK, Møller MN. Submandibular gland excision: longterm clinical outcome in 139 patients operated in a single institution. Eur Arch Otorhinolaryngol. 2013;270(4):1441-6.

5. Beahm DD, Peleaz L, Nuss DW, Schaitkin B, Sedlmayr JC, RiveraSerrano CM, et al. Surgical approaches to the submandibular gland: a review of literature. Int J Surg. 2009;7(6):503-9.

6. Winkel R, Overgaard TI, Balle VH, Charabi S. Surgical results of submandibular gland excision. UgeskrLaeger. 2000;162(40):53547.

7. McGurk M, Makdissi J, Brown JE. Intra-oral removal of stones from the hilum of the submandibular gland: report of technique and morbidity. Int J Oral Maxillofac Surg. 2004;33(7):683-6.
8. Kukuckova B, Svec M. Surgical management of submandibulary gland diseases: ten years of experience. BratislLekListy. 2011;112(5):264-8.

9. Colella G, Garau V, Albanese G. Submandibular sialadenectomy. Our experience. Minerva Stomatol. 1991:40(12):821-3.

10. Lacosta JL, Zabaleta M, Sánchez Galán L. Surgical pathology of submandibular gland. Experience in La Rioja community. An Otorrinolaringollbero Am. 1998;25(6):577-88.

11. Shaha AR, Webber C, DiMaio T, Jaffe BM. Needle aspiration biopsy in salivary gland lesions. Am J Surg. 1990;160(4):373-6.

12. Jayaram G, Verma AK, Sood N, Khurana N. Fine needle aspiration cytology of salivary gland lesions. J Oral Pathol Med. 1994;23(6):25661.

13. Spiro RH. Salivary neoplasms: overview of a 35-year experience with 2,807 patients. Head Neck Surg. 1986;8(3):177-84.

Received on 30/01/2014

Accepted for publication 10/04/2014

Conflict of interest: none.

Source of funding: none.

Address for correspondence:

Rogério Aparecido Dedivitis

E-mail: dedivitis.hns@uol.com.br 